\title{
Pengaruh Konsep Lokalitas Terhadap Nilai Berbelanja Konsumen di Kota Bandung
}

\author{
Tri Widianti Natalia \\ Program Studi Teknik Arsitektur, Universitas Komputer Indonesia, Bandung, Jawa Barat, \\ Indonesia \\ Email: tri.widianti@email.unikom.ac.id
}

\begin{abstract}
ABSTRAK
Pertumbuhan ritel di Indonesia semakin modern, didukung oleh daya beli konsumen yang lebih kuat, membuat konsumen bersedia membayar lebih untuk produk-produk berkualitas tinggi dan suasana yang nyaman. Hal tersebut membuat pengembang Mall di Bandung bersaing untuk mendirikan pusat perbelanjaan. Namun tidak sedikit kegagalan terjadi di pusat perbelanjaan yang memiliki konsep modern pada atribut Mall. Cihampelas Walk dan Paris Van Java menawarkan konsep yang berbeda dengan membawa konsep lokalitas ke mal, tentu akan mempengaruhi nilai belanja konsumen. Penelitian ini bertujuan untuk melihat bagaimana pengaruh konsep lokalitas di pusat perbelanjaan Cihampelas Walk dan Paris Van Java pada nilai konsumen belanja hedonis dan utilitarian di Bandung. Penelitian ini menggunakan metode kualitatif melalui observasi dan wawancara dalam mengumpulkan data. Hasil penelitian menunjukkan bahwa konsep lokalitas di Cihampelas Walk Shopping Mall dan Paris Van Java akan mempengaruhi nilai belanja hedonis dan menjadikannya pilihan belanja utama konsumen, karena memiliki identitas lokal dari Bandung. Konsep lokalitas di CiWalk dan Paris Van Java telah menjadi konsep keberlanjutan pusat perbelanjaan di Bandung.
\end{abstract}

Kata kunci: Konsep lokal, nilai belanja, pusat perbelanjaan.

\section{ABSTRACT}

Retail growth in Indonesia is increasingly modern, supported by stronger consumer purchasing power, making consumers willing to pay more for high quality products and a comfortable atmosphere. Those makes Mall developers in Bandung compete to establish Shopping malls. But not a little failure occurred at Shopping malls that have modern concepts on attributes Mall. Cihampelas Walk and Paris Van Java offer a different concept by bringing the locality concept to the mall, it will certainly affect the shopping value of consumer. This study aims to see how the influence of locality concept at the shopping mall Cihampelas Walk and Paris Van Java on the value of hedonic and utilitarian shopping consumers in Bandung. This research use qualitative method through observation and interview in collecting the data. The results showed that the locality concept at Cihampelas Walk Shopping Mall and Paris Van Java will affect the value of hedonic shopping and make it the main shopping choice of consumers, because it has a local identity from Bandung.The locality concept in CiWalk and Paris Van Java has become a sustainability concept of shopping mall in Bandung.

Keywords: Local concept, shopping value, Shopping mall.

\section{PENDAHULUAN}

Pada awalnya masyarakat Kota Bandung hanya memiliki budaya berbelanja utilitarian, dengan misi harus mendapatkan suatu barang untuk memenuhi kebutuhan sehari harinya, sehingga mereka hanya akan berbelanja ke pasar - pasar tradisional. 
Namun dengan berjalannya waktu, dengan banyaknya Shopping mall yang tumbuh di Kota Bandung, membuat pergeseran budaya berbelanja bagi warga kota Bandung, yang awalnya hanya utilitarian, kini ditambahkan dengan budaya berbelanja hedonik. Marsyarakat dengan nilai belanja hedonik, pergi mengunjungi tempat perbelanjaan lebih dekat pada kegiatan jalan - jalan dengan pencapaian misi tidak harus mendapatkan suatu barang (windows shopping).

Beragamnya budaya berbelanja masyarakat di Kota Bandung, membuat perbedaan pilihan utama terhadap Shopping mall yang ada di Kota Bandung. Ada beberapa Shopping mall yang ramai dikunjungi oleh konsumen hedonik, utilitarian, bahkan oleh konsumen yang hedonik - utilitarian. Semuanya tentunya akan berkaitan erat dengan atribut mall. Seperti yang diungkapkan oleh (Lazarus, 1991 : 353) bahwa kegagalan dan keberhasilan sebuah Shopping mall mengarah pada keberadaan konsep atribut mall yang mempengaruhi respon konsumen. Selanjutnya, menurut (Yue-Teng, Wong, 2012 : 245) mengatakan bahwa atribut mall akan mempengaruhi nilai berbelanja hedonik dan utilitarian yang mengakibatkan perbedaan pola perilaku dalam melakukan aktivitas berbelanja dan pilihan utama Shopping mall.

Dalam perkembangannya, Shopping mall di Kota Bandung banyak mengusung konsep modernitas. Namun dalam kemodernitasan tersebut, CiWalk dan Paris Van Java mengusung konsep Mall yang berbeda, yakni konsep lokalitas yang diaplikasikan pada bangunannya. Konsep lokalitas tersebut merupakan hasil hubungan yang kuat antara pengembang dengan konsumen dalam hal strategi marketingnya. Konsep lokalitas ini diharapkan sebagai konsep keberlanjutan dari sebuah Shopping mall di Kota Bandung.

Konsep yang berbeda ini menjadi masalah penelitian yang menarik untuk dikaji. Sehingga tujuan dari penelitian ini adalah untuk mengetahui bagaimana pengaruh konsep lokalitas pada Shopping mall CiWalk dan Paris Van Java terhadap nilai berbelanja hedonik dan utilitarian konsumen Kota Bandung.

\section{Konsep Lokalitas Pada Perancangan Arsitektur.}

Lokalitas merupakan sebuah lingkungan yang memiliki ciri khas dan suasana berarti terhadap lingkungannya. Suasana itu tampak dari benda yang konkret maupun benda yang abstrak seperti asosiasi kultural dan regional yang dilakukan manusia di tempatnya (Trancik, 1986 : 106). Dapat disimpulkan bahwa lokalitas merupakan karakteristik maupun jiwa yang khas dari suasana yang terlihat dari sesuatu yang konkret seperti arsitektur, karya seni, bahan, rupa, tekstur, warna, maupun benda yang abstrak seperti ekonomi, asosiasi budaya dan regional yang terbentuk dari kegiatan sehari - hari yang dilakukan oleh manusia di tempatnya.

Pencitraan lokalitas sebuah kawasan dapat diakomodasi oleh arsitektur melalui partisipasi semua pihak. Arsitek harus mampu mendengarkan keinginan lingkungan dan mengejawantahkannya sesuai keinginan. Lokalitas dapat menjadi identitas dari suatu lingkungan tempat. Identitas tersebut sangat berkaitan secara langsung dengan pengalaman visual. Identitas ini dapat tercermin dari penyebab terjadinya sebuah perasaan, seperti warna dominan, material dominan, pola bangunan sampai dengan aktivitas dan kegiatan yang berlangsung pada sebuah wilayah yang berkaitan dengan ekonomi, sosial dan budaya dan dipengaruhi oleh kondisi geografis daerah setempat.

Berdasarkan teori Louis Mumford, lokalitas merupakan :

1. Lokalitas tidak hanya terpaku pada kebeasaran sejarah, lebih jauh dari itu harus lebih mengetahui tentang diri kita, lingkungan untuk mengkreasikan sebuah arsitektur yang bertradisis lokal.

2. Lokalitas merupakan sebuah keindahan yang tak terduga, dimana orang - orang yang berada di sebuah tempat dapat merasakan seperti dalam rumah lingkungannya. 
3. Lokalitas dalam membangun tradisi baru harus mampu memanfaatkan teknologi berkelanjutan.

4. Lokalitas harus mampu memberikan kegunaan dan memenuhi kebutuhan penggunannya.

5. Lokalitas harus dapat menempatkan dirinya sebagai sesuatu yang utama dalam nilai kuuniversalan.

Dalam memaknai lokalitas, perlu memaknai tentang sejarah bangunan, material, latar belakang sosial, isu-isu konservasi, konstruksi bangunan. Sehingga pada akhirnya keunikan sebuah lokalitas dalam arsitektur adalah tentang bagaimana material lokal-teknologi dan formasi sosial dapat ditransfer dalam bahasa arsitektur (Sutanto, 2009). Konsep lokalitas dapat diaplikasikan pada perancangan arsitektur dengan :

1. Menyegarkan kembali tradisi dan arsitektur tradisional yang secara perlahan akan tergantikan oleh sesuatu yang modern.

2. Menemukan tradisi dan mengkombinasikannya dengan elemen elemen masa lalu dengan sumber tradisional.

3. Melanjutkan tradisi dengan mempertimbangkan sisi mana dari tradisi yang perlu dilanjutkan demi masa depan dan masa kini.

Menginterpretasikan kembali tradisi melului konsep kontemporer, dimana bentuk tradisional tidak dibuang seluruhnya, namun ditransformasi melalui bentuk yang baru.

Nilai Berbelanja Konsumen Shopping mall Mengetahui nilai berbelanja dari pengunjung mall sangat penting untuk mengetahui kegiatan apa saja yang dilakukan oleh pengunjung mall, nilai berbelanja di mall ini dibagi menjadi dua, yaitu nilai belanja hedonik dan utilitarian (Holbrook dan Hirschman, 1984 : 737). Tidak ada perbedaan nilai belanja dalam generasi, sedangkan dalam gender terdapat perbedaan dalam hal nilai belanja, Perempuan lebih tinggi dalam hal nilai belanja hedonik dibandingkan konsumen laki - laki (Vanessa Jackson, Leslie Stoel, Aquia Brantley, 2011 : 7). Nilai belanja hedonik lebih dekat pada kegiatan jalan - jalan dengan pencapaian misi tidak harus mendapatkan suatu barang dari mengunjungi Mall. Sedangkan nilai belanja utilitarian lebih dekat pada maksud bertujuan dengan pencapaian misi harus mendapatkan suatu barang dari mengunjungi Mall.

Hye Shin Kim (2006) mengkategorikan nilai belanja hedonik dan utilitarian. Kategori nilai berbelanja hedonik diantaranya:

1. Adventure shopping, perasaan berpetualang dan rekreasi menjadi tujuan utama saat berbelanja.

2. Social shopping, jalan - jalan dan interaksi sosial bersama teman dan keluarga menjadi tujuan utama saat berbelanja.

3. Gratification shopping, untuk menghilangkan stress dan berbagai kegiatan yang menjenuhkan, menjadi tujuan utma mereka saat berbelanja

4. Role shopping, mencari kado atau barang unutk teman atau keluarga menjadi tujuan utama mereka berbelanja.

5. Value shopping, mereka akan berbelanja saat ada diskon atau promosi.

6. Idea shopping, mengumpulkan informasi, tren, mode dan produk terbaru menjadi tujuan utama saat berbelanja.

Sedangkan kategori nilai berbelanja utilitarian diantaranya :

1. Achievement, yakni berbelanja mengunjungi mall yang paling penting adalah untuk mendapatkan barang yang telah direncanakan sebelumnya.

2. Efficiency, yakni berbelanja ke mall akan sangat menyenangkan jika barang yang dibutuhkannya dapat diperoleh dengan cepat.

\section{METODE PENELITIAN}

Penelitian ini menggunakan jenis metode kualitatif (Creswell, 2008) dengan kategori sifat penelitian Eksploratif. Pengumpulan Data (Secondary Source), dengan mengkaji literatur tentang pusat-pusat perbelanjaan melalui buku-buku serta penelitian-penelitian dan karya ilmiah sejenis yang mendukung tinjauan mengenai konsep lokalitas dan pusat-pusat perbelanjaan. Pengumpulan 
Data (Primary Source) dilakukan dengan cara observasi dan wawancara terstruktur terhadap konsumen yang sedang mengunjungi CiWalk dan Paris Van Java serta dipilih secara convenience sampling (Kumar, 2005). Pengambilan data dilakukan dengan teknik intercept untuk menghindari kerusakan yang terjadi pada konsep-konsep emosional. Data dianalisis secara kualitatif melalui Eksploratif.

\section{PEMBAHASAN}

\section{Konsep Shopping mall CiWalk}

CiWalk mengusung konsep open air dengan nuansa alam, yang mencerminkan Bandung sebagai Kota Kembang. Dalam pembangunannya, CiWalk mempertahankan hampir setengah pohon - pohon besar yang merupakan eksisting. Klien (pemilik modal) dan arsitek Fauzan Noe'man dapat bersikap empati terhadap ekologi lingkungan hijau yang ada. Dimana 1/3 dari keseluruhan lahan yang ada digunakan untuk bangunan pertokoan, sedangkan 2/3 digunakan untuk area parkir dan lahan hijau.
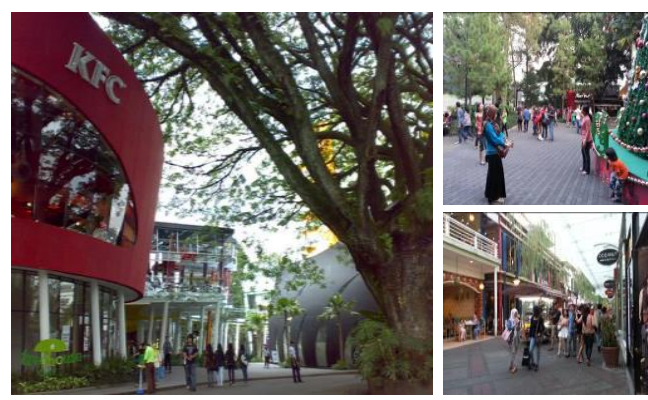

Gbr 1. Suasana Cihampelas Walk Sumber: Natalia. 2017

Segmentasi pasar yang dituju oleh CiWalk adalah konsumen ekonomi menengah sampai menengah ke bawah dengan usia dewasa muda, dimana mereka berusia antara 18 sampai 40 tahun. Hal ini terlihat dengan dibuatnya konsep Young Street untuk usia remaja dan Broadway untuk usia dewasa muda.

\section{Konsep Shopping mall Paris van Java}

Paris Van Java merupakan Resort Lifestyle Place, Shopping mall yang menawarkan pengalaman unik kombinasi dari belanja, makan-makan, dan hiburan. Paris Van Java memiliki nuansa semi open air yang alami dan konsep bangunan yang kental dengan desain Eropa. Hal ini tercermin pada desain tamannya. PVJ dibuat mirip dengan kondisi Paris dengan jajaran toko disepanjang pedestrian.
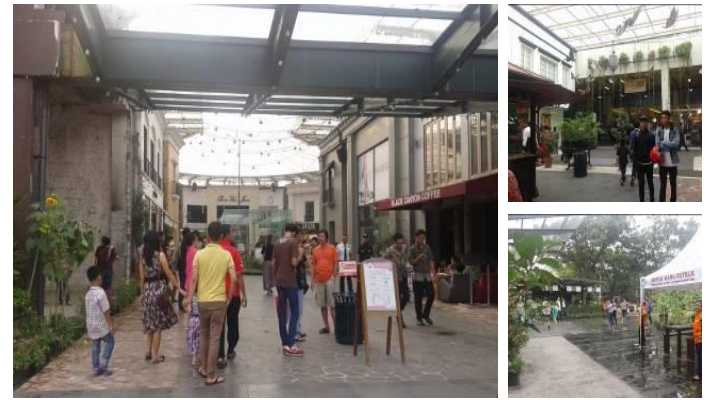

Gbr 2. Suasana Paris Van Java Sumber : Natalia. 2017

Segmentasi pasar yang dituju oleh PVJ adalah konsumen ekonomi menengah sampai menengah ke atas dengan usia remaja sampai usia dewasa akhir, dimana mereka berusia antara 18 sampai 65 tahun.

\section{Tenant Makanan Tradisional Kota Bandung}

Tenant Makanan Tradisional Pada Mall CiWalk

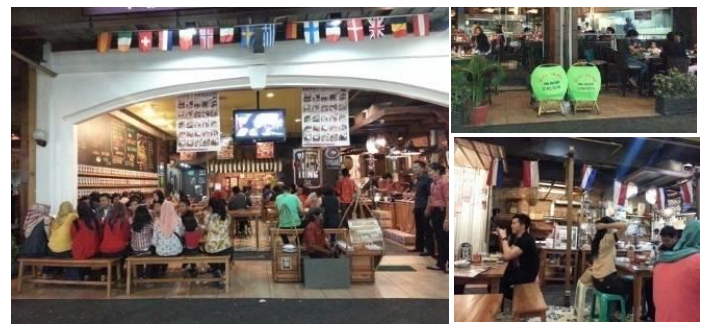

Gbr 3. Tenant Makanan Tradisional Cihampelas Walk

Sumber : Natalia, 2017

Tenant yang didesain tradisional, menjual berbagai macam makanan khas seperti serabi, martabak, tahu gejrot, kerak telor, gulali. Tenant tradisional memanfaatkan teras bangunan untuk menjual makanan tradisional, hal ini membuat aktivitas makanminum pun tidak sekedar pesan, makan, lalu pulang. 
Tenant Makanan Tradisional Pada Shopping mall Paris Van Java

Tenant yang didesain tradisional, menjual berbagai macam makanan khas Kota Bandung dengan memanfaatkan material lokal dan konsep lokal. Tenant tradisional memanfaatkan koridor penghubung untuk menjual makanan tradisional.

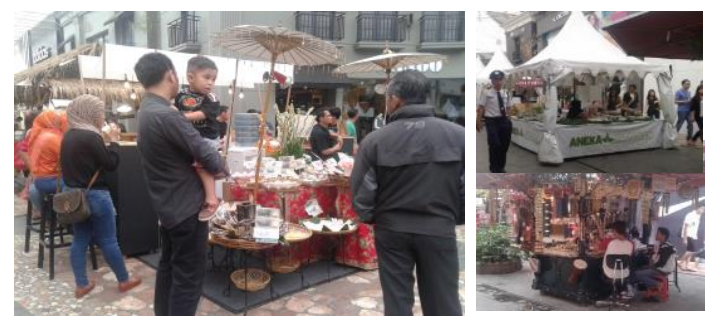

Gbr 4. Tenant Makanan Tradisional PVJ Sumber : Natalia, 2017

Hadirnya tenant - tenant makanan tradisional membuat nilai berbelanja Social Shopping, aktivitas makan-minum tidak sekedar pesan, makan, lalu pulang, namun pengunjung dapat melakukan berbagai interaksi sosial dan aktivitasnya bersama teman - teman dan keluarga. Selain itu, tenant yang menjual berbagai macam makanan khas tradisional juga membuat nilai berbelanja Adventure Shopping, membuat perasaan bertualang pada berbagai jenis makanan, jajanan dan handicraft tradisional.

\section{Budaya "Ngariung" Masyarakat Kota Bandung}

Budaya "Ngariung" diaplikasikan pada beberapa fungsi bangunan pada Mall CiWalk dan Paris Van Java sebagai daya tarik bagi Mall tersebut. dengan segmentasi pasarnya adalah masyarakat Kota Bandung yang sebagian besar senang berkumpul dengan teman - teman atau keluarga.

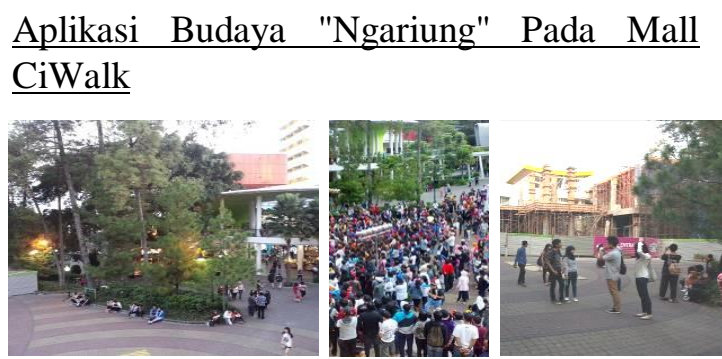

Gbr 5. Budaya "Ngariung" Pada Plaza Mall CiWalk
Budaya "Ngariung" di Mall CiWalk teraplikasi pada bagian bangunan plaza utama yang merupakan spatio temporal, yang digunakan pengunjung sebagai area berkumpul yang merupakan identitas masyarakat Kota Bandung masa lalu yang biasa disebut dengan istilah "ngariung". Terkadang Plaza ini digunakan untuk pertunjukan seni budaya khas Kota Bandung.

Aplikasi Budaya "Ngariung" Pada Mall Pris Van Java

Budaya "Ngariung" di Mall Paris Van Java teraplikasi pada sebuah kolam ikan besar di depan kafe-kafe yang berjajar. Kolam ikan itu hanya terisi hingga sekitar tahun 2007, namun sekarang dikosongkan dan berubah menjadi sebuah plaza temporer, yang biasa digunakan sebagai berkumpul pengunjung, dan sebagai tempat pentas dan festival.
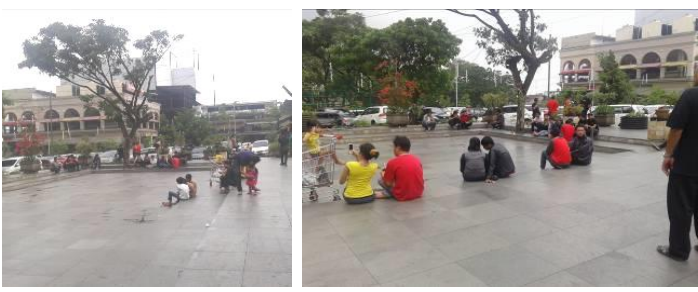

Gbr 6. Budaya "Ngariung" Pada Plaza Mall PVJ Sumber : Natalia, 2017

Budaya "Ngariung" masyarakat Kota Bandung teraplikasi pada bangunan Plaza Mall CiWalk dan Paris Van Java membuat nilai berbelanja Social Shopping. Karena pada area plaza didukung oleh oleh street furniture berupa tempat duduk yang berada di bawah pohon, baik berupa kursi maupun tangga. Sehingga suasana teduh akan tercipta dan membuat pengunjung senang berlama - lama untuk berkumpul, duduk duduk dan interaksi dengan teman dan keluarga.

\section{Suasana Alam Kota Kembang Sebagai Identitas Kota Bandung}

Konsep CiWalk dan Paris Van Java yang dinilai berbeda dengan konsep mall lainnya 
yang berda di kota Bandung, menjadikan mall tersebut memiliki identitas lokal dari Kota Bandung. Konsep mall yang tebuka dan bersatu dengan alam, serta pepohonan besar yang telah berumur puluhan tahun yang dipertahankannya, menjadikan ciri khas Kota Kembang yang merupakan sebutan lain untuk kota Bandung, karena pada jaman dahulu kota ini dinilai sangat cantik dengan banyaknya pohon-pohon dan bunga-bunga yang tumbuh.

Suasana Alam Kota Kembang Pada Mall CiWalk

Suasana alam yang menyatu antara ruang dalam dan ruang luar serta didominasi oleh ruang luar dengan pepohonan, taman terbuka, dan pedestrian path yang teduh mencitrakan ciri khas dari Kota Bandung sebagai Kota Kembang. Suasana alam ini membuat pengunjung CiWalk tidak selalu terkurung dalam bangunan raksasa namun diajak berjalan di udara terbuka.

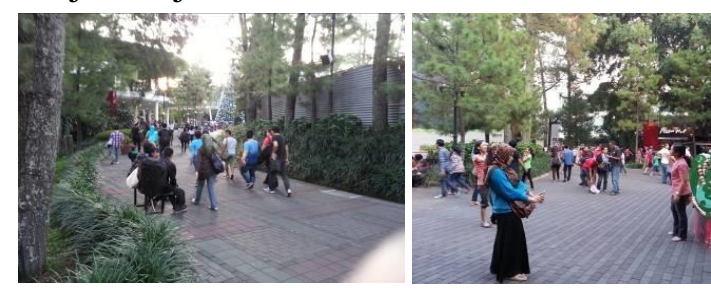

Gbr 7. Suasana Alam Kota Kembang Pada Mall CiWalk

Sumber : Natalia, 2017

Suasana Alam Kota Kembang Pada Mall Paris Van Java

Keberadaan Gardenice pada Mall Paris Van Java yang merupakan taman terbuka pada bagian rooftop serta memiliki visual akses ke pemandangan kota Bandung, hal tersebut mencirikan sebagai sebuah kota yang memiliki taman pada bangunanannya. Seperti halnya Bandung sebagai Kota Kembang.
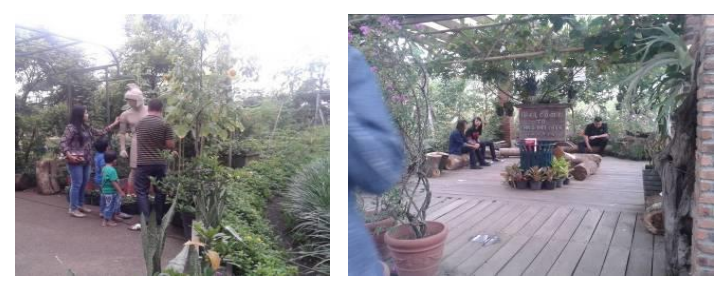

Gbr 8. Suasana Alam Kota Kembang Pada Mall PVJ

Sumber : Natalia, 2017

Suasana alam kota kembang yang teraplikasi pada tatanan ruang bangunan mall CiWalk dan Paris Van Java, membuat nilai berbelanja Adventure Shopping, dimana pengunjung merasakan perasaan bertualang saat berbelanja. Pengunjung merasa diajak berjalan untuk menjelajah ke gerai - gerai yang berjajar di area luar dengan mengoptimalkan suasana alam dan udara Kota Bandung yang nyaman.

Selain nilai berbelanja Adventure Shopping nuansa alam kota kembang membuat nilai berbelanja Gratification Shopping, dimana dengan kehadiran taman dengan nuansa alam terbuka membuat pengunjung merasa tidak pengap dan bosan berada dalam satu bangunan yang tertutup, sehingga membuat pengunjung merasa rileks dan dapat melepaskan kejenuhan serta rutinitas kesehariannya.

\section{Penggunaan Material Lokal Pada Bangunan Mall}

Untuk lebih memberikan identitas lokal pada konsep bangunan Mall CiWalk dan Paris Van Java, digunakanlah material lokal, materila lokal ini merupakan material yang mudah ditemui dan didapat di Kota Bandung.

Penggunaan Material Lokal Pada Bangunan CiWalk

Beberapa elemen dan material lokal yang diaplikasikan pada bangunan CiWalk lebih banyak terdapat pada tenant yang mengusung konsep tradisional. Seperti penggunaan material batu bata ekspos, kayu, batu kali, bahkan ditambahkan dengan elemen tradisional seperti pekakas "boboko" atau tempat nasi tradisional sunda yang diletakkan di bagian atas sebagai elemen furnitur.
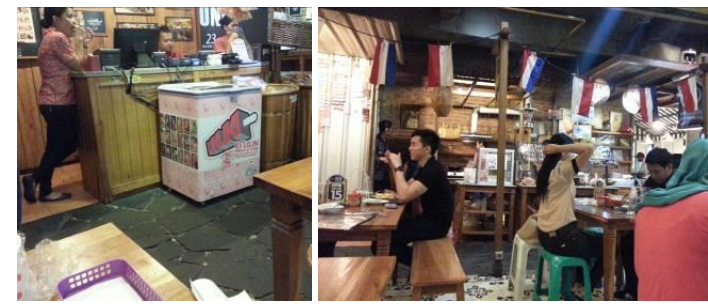


\section{Gbr 9. Material Dan Elemen Lokal Pada Mall CiWalk \\ Sumber : Natalia, 2017}

Penggunaan Material Lokal Pada Bangunan Paris Van Java

Material lokal pada Mall Paris Van Java dapat ditemui pada beberapa bagian bangunan. Diantaranya, tenant - tenant makanan tradisional yang menggunakan atap jerami dengan konstruksi bambu, pada koridor penghubung menggunakan kombinasi batu bata, batu alam, dan sebagian besar menggunakan kayu untuk area pejalan kaki. Sedangkan bagian atap koridor menggunakan atap pergola dengan konstruksi kayu yang dikombinasikan dengan tumbuhan rambat sebagai penutup atapnya.

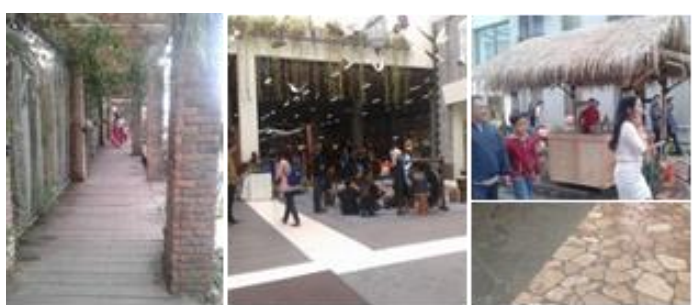

Gbr 10. Material Lokal Pada Mall PVJ Sumber : Natalia, 2017

Penggunaan material lokal pada Mall CiWalk dan Paris Van Java membuat nilai berbelanja Adventure Shopping. Hal ini karena penggunaan material kayu pada area koridor yang dapat meminimalisir rasa pegal yang terjadi saat berpetualang jalan mengelilingi tenant - tenant. Sehingga pengunjung merasa nyaman untuk berkeliling dari gerai satu ke gerai lainnya.

Selain itu, penggunaan material lokal yang beragam membuat pengunjung merasa berada di tempat yang tidak biasa atau berbeda. Sehingga pengunjung merasa ingin mencari tahu material lokal lainnya pada area atau bagian lain dari mall yang dikunjunginya. Hal tersebut secara tidak langsung membuat pengunjung dapat melihat etalase toko, yang membuat kegiatan windows shopping pengunjung tidak membosankan untuk melihat - lihat display toko dan membuat pengunjung mudah mengumpulkan informasi tentang tren baru, mode, dan produk baru dari satu toko ke toko lainnya, dengan kata lain, kegiatan tersebut termasuk dalam nilai berbelanja Idea Shopping.

\section{Vegetasi Setempat Yang Dipertahankan}

Konsep lokal pada Mall CiWalk dan Paris Van Java salah satunya teraplikasi karena kearifan arsitek dalam mengejawantahkan konsep alam pada produk desain bangunan CiWalk dan Paris Van Java yang tentunya telah disinergikan dengan segmentasi pasar yang dituju. Kearifan dalam konsep alam salah satunya adalah masih mempertahankan sebagian besar vegetasi setempat yang telah berusia puluhan tahun.

Vegetasi Setempat Yang Dipertahankan Pada Mall CiWalk

Pada pembangunan Mall CiWalk, pepohonan besar yang telah berumur puluhan tahun sangat dipertahankan, hal ini untuk memberikan suasana alam yang teduh dan menjadikan ciri khas dari Kota Bandung sebagai Kota Kembang yang merupakan sebutan lain untuk kota ini. Karena pada jaman dahulu kota ini dinilai sangat cantik dengan banyaknya pohon-pohon dan bungabunga yang tumbuh.
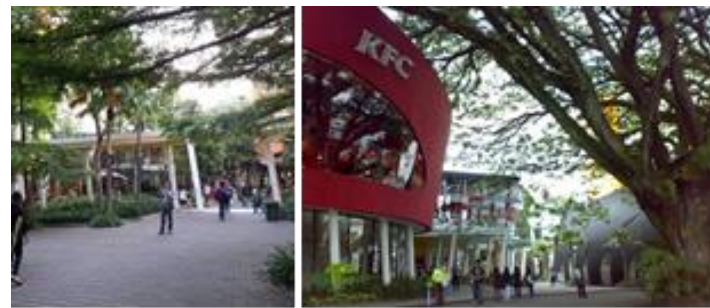

Gbr 11. Vegetasi Yang Dipertahankan Pada Mall CiWalk

Sumber : Natalia, 2017

Vegetasi Setempat Yang Dipertahankan Pada Mall Paris Van Java

Vegetasi setempat yang dipertahankan di Mall Paris Van Java terdapat pada area parkir. Dimana pada lahan parkir sebagian besar pepohonan besar masih dipertahankan. Hal ini untuk memberikan efek peneduh pada area parkir. 


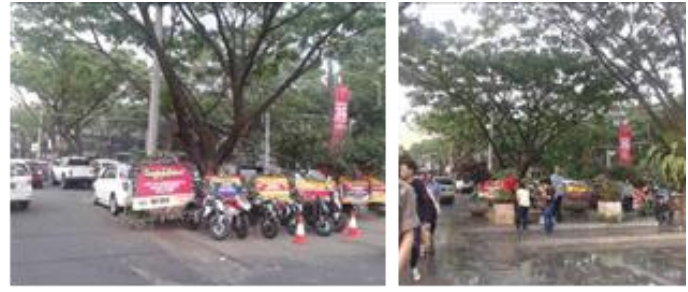

Gbr 12. Vegetasi Yang Dipertahankan Pada Mall PVJ

Sumber : Natalia, 2017

Pepohonan besar dengan umur puluhan tahun yang dipertahankan pada Mall CiWalk dan Paris Van Java membuat nilai berbelanja Social Shopping, dimana pepohonan besar yang dipertahankannya telah memberikan efek peneduh dan suasana alam yang sejuk layaknya Kota Bandung tempo dulu. Dengan udara yang sejuk, segar dan efek teduh, membuat kedua mall tersebut menjadi salah satu Shopping mall tujuan utama konsumen di Kota Bandung. Terlebih untuk Mall Paris Van Java yang memiliki lahan parkir yang nyaman dengan udara yang sejuk, tanpa harus memasuki lantai basement. Sehingga lahan parkir pada Mall Paris Van Java menjadi salah satu pertimbangan utama dan daya tarik pengunjung untuk mengunjungi Shopping mall di Kota Bandung.

\section{SIMPULAN}

Konsep lokalitas pada Shopping mall CiWalk dan Paris Van Java teraplikasi pada bagian landscape dan bangunan. Diantaranya aplikasi pada tenant makanan tradisional/ khas Kota Bandung, budaya "ngariung" masyarakat Kota Bandung, suasana alam kota kembang sebagai identitas Kota Bandung, penggunaan material lokal pada bangunan mall, serta vegetasi setempat yang dipertahankan.

Konsep lokalitas pada landscape dan tatanan massa Shopping mall CiWalk dan Paris Van Java memfasilitasi seluruh kegiatan yang berhubungan dengan nilai berbelanja hedonik dengan misi tidak harus mendapatkan barang yang direncanakan, seperti fasilitas untuk berkumpul atau interaksi sosial (Social Shopping), menjelajah berbagai macam gerai (Adventure Shopping), kegiatan refreshing (Gratification Shopping), dan kegiatan windows shopping (Idea Shopping).

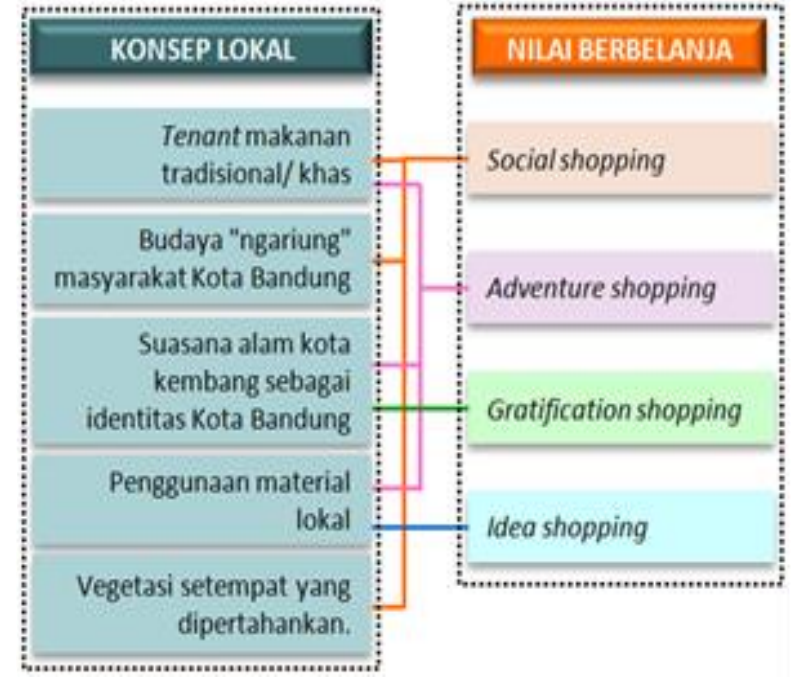

\section{Diagram 1. Pengaruh Konsep Lokal Terhadap Nilai Berbelanja Sumber : Natalia, 2017}

Keberhasilan Shopping mall CiWalk dan PVJ bukan saja terjadi karena kekuatan pemilik modal, namun tentunya merupakan keberhasilan jaringan interaksi antara klien, arsitek, dan penyewa tenant. Kearifan arsitek dalam mengejawantahkan konsep lokalitas alam pada produk desain bangunan CiWalk dan PVJ yang tentunya telah disinergikan dengan segmentasi pasar yang dituju. Hal ini terbukti dengan keberhasilan Mall CiWalk dan Paris Van Java menempati urutan pertama sebagai Mall yang merupakan tujuan utama para mahasiswa yang ada di kota Bandung (Sari, 2011 : 160).

Shopping mall CiWalk dan Paris Van Java memberikan identitas tersendiri terhadap suasana perbelanjaan tempo dulu di Kota Bandung dengan suasana alam seperti kota kembang. Konsep lokalitas mampu untuk menempatkan identitas sebagai hal yang utama dibandingkan konsep modernitas yang bersifat universal.

Konsep lokalitas tersebut menjadi sebuah daya tarik konsumen untuk mengunjungi Shopping mall CiWalk dan Paris Van Java. Konsep lokal ini merupakan sebuah konsep keberlanjutan dari sebuah Shopping mall di Kota Bandung. Keberlanjutan untuk menjadi sebuah Mall yang tetap dapat bertahan dari masa ke masa untuk selalu ramai dikunjungi 
oleh masyarakat Kota Bandung yang mulai memiliki budaya berbelanja hedonik.

Konsep lokalitas ini membuktikan bahwa tidak harus konsep modernitas yang dapat menjadi daya tarik pengunjung masa kini untuk mengunjungi Shopping mall. Justru konsep lokalitas menjadi ciri khas yang unik untuk menjadikan daya tarik pasar. Lokalitas telah dianggap sebagai senjata yang tepat untuk menahan lajunya ruang-ruang kapitalis yang telah menyusup dalam kehidupan manusia di dunia modern ini, khususnya dalam bangunan Shopping mall.

\section{DAFTAR PUSTAKA}

[1] Creswell, J.W.(2008). Research Design: Qualitative, Quantitative, and Mixed Methods Approaches. California: Sage Publications, Inc.

[2] Holbrook, M.B., Chestnut, R.W., Oliva, T.A., Greenleaf, E.A., 1984. Play as a consumption experience: the roles of emotion, performance, and personality in the enjoyment of games. Journal of Consumer Research 11, 728-739.

[3] Jackson, Vanessa; Stoel, Leslie dan Brantley, Aquia.(2011). Mall attributes and shopping value: Differences by gender and generational cohort. Journal of Retailing and Consumer Services 18 (2011), 1-9.

[4] Kim, Hye-Shin.(2006). Using Hedonic and Utilitarian Shopping Motivations to Profile Inner City Consumers. Journal of Shopping Center Research, Volume 13, Number 1, 57-79

[5] Kim,SS., Timothy, JD., dan Hwang, J.(2011). Understanding Japanese tourists' shopping preferences using the Decision Tree Analysis method. Journal of Tourism Management 32 (2011).544-554

[6] Kumar, Ranjit. (2005). Research Methodology. New Delhi: Sage Publications India Pvt Ltd

[7] Lazarus, R.S., 1991. Progress on a cognitive-motivational-relational theory of emotion. American Psychologist 46, 819-834.
[8] Mumford, Lewis. (1961). The City in History. United State: Harcourt, Brace $\&$ World, Inc. Diakses pada 13

Februari 2015 dari WorldWideWeb: http://www.junctionzero.com/websites/i lumarta/berita/07_memaknailokalitas.ht $\mathrm{m}$.

[9] Sari, A.A., Kusuma, H.E., \& Tedjo, Baskoro.(2011). A Strategic Planning for a College Student-Segment Shopping mall. International Research Journal of Business Studies ,4(2), 157169.

[10] Sutanto, Agustinus.(2009). Memaknai Lokalitas. Diakses pada 8 Oktober 2013 dari WorldWideWeb:http://www.psikologi.t arumanagara.ac.id/s2/wpcontent/upload s/2009/11/tata-cara-penulisan-daftarpustaka.doc.

[11] Trancik, Roger. (1986). ,Finding Lost Space: Theories of Urban Design. Canada : John Wiley \& Sons, Inc.

[12] Wong, Yue-Teng., Syuhaily Osman., Askiah Jamaluddin., Benjamin Chan Yin-Fah. (2012). Shopping motives, store attributes and shopping enjoyment among Malaysian youth. Journal of Retailing and Consumer Services 19, 240-24. 